\title{
EFEKTIVITAS SENAM AEROBIK TERHADAP KONTROL KADAR GLUKOSA DARAH PADA PASIEN DM TIPE 2
}

\author{
${ }^{1}$ Ratna Dewi, ${ }^{2}$ Surya Agus Susilawaty \\ ${ }^{1}$ Dosen Prodi S-1Keperawatan, STIKes Imelda, Jalan Bilal Nomor 52 Medan, \\ ${ }^{2}$ Alumni STIKes Imelda \\ Email: ratnadewi2550@gmail.com
}

\begin{abstract}
ABSTRAK
Diabetes mellitus (DM) adalah suatu kelompok penyakit metabolik dengan karakteristik hiperglikemia yang terjadi karena kelainan sekresi insulin, kerja insulin, atau kedua-duanya, senam aerobik merupakan latihan yang menggerakkan seluruh otot, terutama dengan otot besar dengan gerakan yang terus menerus, berirama dan berkelanjutan sehingga kemungkinan dapat mengontrol kadar glukosa darah. Tujuan penelitian ini menganalisa rerata selisih kadar glukosa darah sebelum dan sesudah melakukan senam aerobik. Penelitian ini merupakan penelitian dengan pendekatan eksperimen semu/quasi eksperimen dengan menggunakan rancangan one group pre and post test design yaitu rancangan perlakuan menggunakan satu kelompok sampel yang sama dengan dua penilaian setelah perlakuan. Populasinya adalah seluruh pasien DM tipe 2 di Rumah Sakit USU, diambil sampel 38 partisipan. Analisis dengan uji paired simple $t$ test. Hasil menunjukkan rata-rata kadar glukosa darah sebelum dilakukan senam aerobik yaitu $195.89 \mathrm{mg} / \mathrm{dL}$ dan sesudah yaitu $173.18 \mathrm{mg} / \mathrm{dl}$. Selisih rerata kadar glukosa darah sebelum dan sesudah senam aerobik yaitu $22.71 \mathrm{mg} / \mathrm{dL}$. ada pengaruh signifikan senam aerobik terhadap kontrol kadar glukosa darah pada penderita DM tipe 2 di Rumah Sakit USU (p-value 0.000). Kesimpulan dari penelitian ini adalah ada pengaruh efektivitas senam aerobik terhadap kontol kadar gula darah pada penderita DM tipe 2 di Rumah Sakit Universitas Sumatera Utara.
\end{abstract}

Kata Kunci: Senam Aerobik, Kadar Glukosa Darah, Dm Tipe 2

\section{PENDAHULUAN}

Jumlah penderita DM di dunia dari tahun ke tahun menunjukkan adanya peningkatan. Berdasarkan data dari International Diabetes Federation (IDF) 2014, jumlah penderita DM sebanyak 366 juta jiwa di tahun 2011 meningkat menjadi 387 juta jiwa di tahun 2014 dan diperkirakan akan bertambah menjadi 592 juta jiwa pada tahun 2035. Jumlah kematian yang terjadi pada tahun 2014 sebanyak 4,9 juta jiwa dimana setiap tujuh detik terdapat satu kematian dari penderita DM di dunia (PERKENI, 2015).

Menurut WHO dalam Arofah (2015) sebanyak $80 \%$ penderita DM di dunia berasal dari negara berkembang salah satunya adalah Indonesia. Laporan Riset Kesehatan Dasar (Riskesdas) tahun 2013 prevalensi penderita DM pada tahun 2013 $(2,1 \%)$ mengalami peningkatan dibandingkan pada tahun $2007(1,1 \%)$. Prevalensi DM tertinggi terdapat di provinsi D.I Yogyakarta dengan nilai prevalensi $2,6 \%$, yang kemudian diikuti oleh D.K.I Jakarta dengan 2,5\% dan Sulawesi Utara $2,4 \%$ dan untuk Sumatera Utara 2,3\%.
Menurut Perkumpulan Endokrinologi Indonesia (PERKENI) tahun 2015 terdapat empat pilar penatalaksanaan DM yaitu; edukasi, terapi gizi medis, latihan jasmani/aktivitas fisik serta intervensi farmakologis. Aktivitas fisik akan meningkatkan rasa nyaman, baik secara fisik, psikis maupun sosial dan tampak sehat. Bagi pasien DM, aktivitas fisik dapat mengurangi resiko kejadian kardiovaskuler serta meningkatkan harapan hidup.

Dewasa ini banyak sekali programprogram aktifitas fisik yang ditawarkan untuk mencapai tingkat kebugaran jasmani yang diharapkan, diantaranya adalah senam aerobik, bersepeda, renang, jogging, berlari dan permainan seperti bulu tangkis, sepak bola, tenis dan sebagainya. Senam aerobik merupakan latihan yang menggunakan seluruh otot terutama otot-otot besar, dengan gerakan yang terus menerus, berirama dan berkelanjutan. Pada pelaksanaannya senam aerobik menggunakan iringan musik yang antara lain berguna untuk meningkatkan motivasi latihan dan kecepatan latihan. Dengan demikian intensitas latihan dapat diatur dengan pengaturan tempo musik yang mengiringinya (Purwanto, 2011). 
Berdasarkan hasil penelitian yang dilakukan oleh Berawi, Fiana, dan Putri (2010) tentang senam aerobik terhadap KGD pada peserta senam aerobik di pusat kebugaran sonia Bandar Lampung di dapatkan bahwa senam aerobik dapat mempengaruhi penurunan KGD. Senada dengan penelitian Indriani, Supriyatni, dan Santoso (2014) tentang senam aerobik terhadap KGD pada pasien DM tipe 2 di Puskesmas Bukateja Purbalingga di dapatkan bahwa senam aerobik dapat mempengaruhi penurunan KGD rata - rata sebesar 30,14\%.

Berdasarkan data rekam medik dari bulan Juli sampai Desember 2017 didapatkan pasien dengan DM tipe 2 yang berobat di poli Rumah Sakit Universitas Sumatera Utara (USU) didapatkan sebanyak 1.191 orang. Pasien dengan DM tipe 2 tidak mendapatkan intervensi aktifitas fisik yang dianjurkan oleh rumah sakit, jadi rumah sakit hanya memberikan pelayanan tentang farmakologis atau obat. Oleh karena itu peneliti tertarik untuk mengetahui Efektivitas Senam Aerobik terhadap Kontrol KGD pada Pasien DM tipe 2 di Rumah Sakit USU.

\section{METODE}

Tujuan dari penelitian untuk menganalisis beda rerata selisih nilai KGD pasien DM tipe 2 sebelum dan sesudah intervensi senam aerobik. Penelitian ini menggunakan desain quasi eksperimen dengan terapi non farmakologis. Populasi penelitian adalah seluruh pasien DM tipe 2 yang yang berobat di Poli RS USU dengan menggunakan metode purposive sampling sebanyak 38 partisipan kelompok intervensi yang melakukan senam aerobik (selama 30 menit, dilakukan 3x seminggu). Pengambilan data dilakukan pre test cek KGD sebelum dan sesudah senam aerobik dengan menggunakan glukometer. Analisis data menggunakan analisis univariat, analisis bivariat dengan uji dependent sampel t-test (paired t test).

\section{HASIL}

Tabel 1. Distribusi Frekuensi Responden Menurut Umur, Jenis Kelamin, Pendidikan, dan Lama Menderita DM Tipe 2 di RS USU

\begin{tabular}{|c|c|c|c|}
\hline No & Karakteristik & $\mathbf{f}$ & $\%$ \\
\hline 1 & Usia (Tahun) & & \\
\hline & $45-49$ & 1 & 2,6 \\
\hline & $50-54$ & 12 & 31,6 \\
\hline & $55-60$ & 25 & 65,8 \\
\hline 2 & Jenis Kelamin & & \\
\hline & Laki-laki & 12 & 31,6 \\
\hline & Perempuan & 26 & 68,4 \\
\hline 3 & Pendidikan & & \\
\hline & SD & 7 & 18,4 \\
\hline & SMP & 3 & 7,9 \\
\hline & SMA & 21 & 55,3 \\
\hline & Sarjana & 7 & 18,4 \\
\hline 4 & \multicolumn{3}{|l|}{ Lama Menderita } \\
\hline & $1-5$ & 20 & 52,6 \\
\hline & $6-10$ & 18 & 47,4 \\
\hline 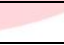 & Total & 38 & 100 \\
\hline
\end{tabular}

Tabel 2. Distribusi Frekuensi KGD Pasien DM Tipe 2 di RS USU sebelum dan Sesudah Melakukan Senam Aerobik

\begin{tabular}{lccccc}
\hline No & Keterangan & Mean & $\begin{array}{c}\text { Minimum } \\
(\mathbf{g r} / \mathbf{d l})\end{array}$ & $\begin{array}{c}\text { Maksimum } \\
(\mathbf{g r} / \mathbf{d l})\end{array}$ & SD \\
\hline 1 & KGD Sebelum Senam Aerobik & 195,89 & 139 & 242 & 26,663 \\
\hline 2 & KGD Sesudah Senam Aerobik & 173,18 & 107 & 235 & 31,980 \\
\hline
\end{tabular}

Tabel 3. Beda Rerata Nilai KGD Sebelum dan Sesudah Melakukan Senam Aerobik pada Pasien DM Tipe 2 di RS USU

\begin{tabular}{|l|c|c|c|}
\hline Kadar Glukosa Darah (KGD) & Mean & $\boldsymbol{p}$-value & Std. Deviation \\
\hline KGD Sebelum Senam Aerobik & 22,711 & 0,000 & 13,053 \\
\hline
\end{tabular}

Tabel 3 menunjukkan hasil uji paired aerobik nilai $p$-value $=0.000<0.005$ dengan simple $t$ test pada penderita DM tipe 2 rentang rerata KGD sebelum dan sesudah sebelum dan sesudah dilakukan senam melakukan senam aerobik, hal ini 
menunjukkan perhitungan statistik bermakna mengartikan bahwa efektivitas senam aerobik terhadap kontrol KGD baik.

\section{PEMBAHASAN}

\section{Kadar Glukosa Darah (KGD) Pasien DM Tipe 2 di RS USU Sebelum Dilakukan Senam Aerobik}

Hasil penelitian menunjukkan bahwa nilai rata-rata KGD sebelum melakukan senam aerobik sebesar $195.89 \mathrm{mg} / \mathrm{dL}$, nilai deviasi sebesar 26.663, dengan KGD terendah sebesar $139 \mathrm{mg} / \mathrm{dL}$ dan KGD tertinggi sebesar $242 \mathrm{mg} / \mathrm{dL}$. Hal ini dapat dikaitkan dengan usia dan jenis kelamin. Hasil penelitian ini sejalan dengan penelitian yang dilakukan oleh Astuti (2016) yang menghasilkan kesimpulan bahwa rata-rata KGD sebelum tindakan sebesar 183.17 $\mathrm{mg} / \mathrm{dL}$, melihat perbandingan hasil rata-rata KGD tersebut berarti sebelum melakukan tindakan KGD penderita DM tipe 2 rata-rata sebesar $183,17 \mathrm{mg} / \mathrm{dL}$.

Aktifitas fisik yang kurang mempunyai hubungan yang bermakna dengan gangguan ekstremitas dimana aktifitas yang rendah, salah satunya tidak teratur berolahraga berisiko terjadinya gangguan gerak maupun obesitas. Masalah lain yang sering terjadi pada lansia terkait pengendalian KGD adalah sering terjadi kebosanan, tidak adanya motivasi dan keputusan. Menurut teori Helath Promotion Model perlu diberikan intervensi melalui edukasi, supporting dari perawat dengan menerapkan prinsip-prinsip teori psikososial, sehingga permasalahan kurangnya motivasi untuk menjaga kesehatan pada lansia dapat diatasi.

\section{Kadar Glukosa Darah Pasien DM Tipe 2 di RS USU Sesudah Dilakukan Senam Aerobik}

Hasil penelitian ini menunjukkan bahwa rata-rata nilai KGD pada penderita DM tipe 2 sesudah melakukan senam aerobik sebesar $173.18 \mathrm{mg} / \mathrm{dL}$, nilai standar deviasi sebesar 31.980 dengan KGD terendah setelah melakukan senam aerobik sebesar $107 \mathrm{mg} / \mathrm{dL}$ dan nilai KGD tertinggi setelah melakukan senam aerobik sebesar $235 \mathrm{mg} / \mathrm{dL}$. Penelitian ini tidak ditemukan terjadinya peningkatan setelah melakukan aktifitas latihan senam aerobik.

Latihan fisik dengan dosis yang tepat dapat menimbulkan proses adaptasi pada sistem, yaitu sistem saraf, sistem hormon, sistem kardiorespirasi, sistem metabolisme, sistem neuromuskuloskeletal dan sistem ketahanan tubuh. Setelah latihan fisik atau berolahraga selama 10 menit kebutuhan glukosa sewaktu akan meningkat sampai 15 kali dari jumlah kebutuhan pada keadaan bisasa. Olahraga pada penderita DM dapat meyebabkan terjadinya peningkatan pemakaian glukosa oleh otot aktif, sehingga secara langsung olahraga dapat menurunkan glukosa darah (Fajar \& Siswantoyo, 2006).

Hasil penelitian ini sejalan dengan penelitian PERKENI (2015) yang menyebutkan bahwa kegiatan jasmani sehari-hari dan latihan secara teratur (3 kali seminggu selama kurang lebih 30 menit) merupakan salah satu pilar dalam pengelolaan DM tipe 2. Latihan jasmani yang dianjurkan berupa latihan jasmani yang bersifat aerobik dengan intensitas sedang (50-70\% denyut jantung maksimal) seperti: jalan cepat, bersepeda santai, jogging, dan berenang.

\section{Efektifitas Senam Aerobik Terhadap Kadar Glukosa Darah Pasien DM Tipe 2 di RS USU}

Hasil penelitian ini menunjukkan terdapat pengaruh signifikan senam aerobik pada pasien DM tipe 2 di Rumah Sakit USU. Olahraga aerobik dilakukan pada tingkat intensitas sedang untuk jangka waktu tertentu. Oksigen digunakan untuk membakar lemak dan gula untuk menghasilkan adenosin trifosfat yang merupakan pembawa dasar energi di tingkat sel (Lynne, 2012). Senam aerobik dapat meningkatkan kerja dan fungsi jantung, paru dan pembuluh darah yang ditandai dengan denyut nadi istirahat menurun, penumpukan asam laktat berkurang, meningkatkan HDL kolesterol, dan mengurangi aterosklerosis.

Pada penelitian ini dilakukan senam aerobik $3 \mathrm{x}$ dalam seminggu dilakukan selama 30 menit setiap kali latihan. Terjadi penurunan KGD sebesar $28.3 \mathrm{mg} / \mathrm{dL}$ dengan nilai $p=0.000$. Hal ini sejalan dengan penelitian Utomo (2012) yang menjelaskan bahwa terdapat perbedaan penurunan KGD antara kelompok yang terpapar dan kelompok tidak terpapar (nilai $p=0.0001$ ). Penurunan rata-rata KGD sewaktu pada kelompok terpapar 2,3 kali lebih besar dari pada kelompok yang tidak melakukan 
aktifitas fisik ( $31,5 \mathrm{mg} / \mathrm{dL}$ berbanding 13.5 $\mathrm{mg} / \mathrm{dL})$.

Hasil penelitian ini juga sejalan dengan penelitian Astuti (2016) yang menjelaskan bahwa terdapat hubungan negatif antara aktifitas fisik dengan KGD pada pasien DM tipe 2 ( $p=0.0001$ dan nilai $r=-0.433$ ), artinya bahwa kegiatan senam aerobik yang dilakukan secara teratur akan dapat menurunkan ataupun mengkontrol KGD pada pasien DM tipe 2, begitu juga sebaliknya apabila kegiatan senam aerobik tidak dilakukan secara teratur maka KGD pada pasien penderita DM tipe 2 tidak akan terkontrol.

\section{KESIMPULAN}

Berdasarkan hasil penelitian yang telah dilakukan, maka di peroleh kesimpulan bahwa Ada pengaruh efektivitas senam aerobik terhadap kontol KGD pada penderita DM tipe 2 di Rumah Sakit USU ( $p$-value = 0.000) dengan beda rerata sebelum dan sesudah melakukan senam aerobik yaitu $28.30 \mathrm{mg} / \mathrm{dl}$.

\section{SARAN}

1. Diharapkan setelah dilakukasn peneliti ini klien tetap melakukan aktifitas fisik olahraga secara teratur khususnya melakukan senam aerobik dalam mengkontrol kadar gula darah pada pasien DM tipe 2.

2. Hasil penelitian ini diharapkan dapat dijadikan upaya mengembangkan program penatalaksaan berupa senam aerobik terhdap control kadar gula darah pada pasien DM tipe 2.

3. Diharapkan perawat dapat menerapakan intervensi udalam mengontrol kadar gula darah pada pasien penderita DM tipe 2 dengan menggunakan cara aktifitas fisik olahraga seperti senam aerobik.

4. Diharapkan peneliti selanjutnya dapat melanjutkan penelitian ini dengan mengembangkan lamanya intervensi dan waktu latihan senam aerobik, pagi atau sore hari.

DAFTAR PUSTAKA
American Diabetes Association. (2015). Standards of Medecal Care in Diabeties-2015. Diabetes Care, Vol 38.

Arikunto, S. (2010). Prosedur Penelitian Suatu Pendekatan Praktik. Jakarta: Rineka Cipta.

Astuti, D. (2016). Pengaruh Senam Aerobik terhadap Kadar Gula Darah Puasa Penderita Diabetes mellitus Tipe 2 pada Kelompok Prolanis UPT PUSKESMAS Wonogiri I. Surakarta: Stikes Kusuma Husada.

Barnes, D.E. (2012). Program Olahraga Diabetes. Yogyakarta: Citra Aji Paramana.

Guyton and Hall. (2007). Buku Ajar Fisiologi Kedokteran. Jakarta: EGC.

Hariyanto, E. (2013). Hubungan Aktifitas Fisik dengan Kadar Gula Darah Puasa Pada Pasien Diabetes Melitus Tipe-2 di Rumah Sakit Daerah Kota Cilegon. Jakarta: Universitas Islam Negeri Syarif Hidayatullah.

Hidayat, Alimul A.A. (2010). Metode Penelitian Kesehatan Paragdima Kuantitatif. Jakarta: Health Books.

Holt, Richard, I.G. et al. (2010). Textbook of diabetes. Fourth Edition. UK: A John Wiley \& Sons, Ltd. UK.

Holt, T. , Kumar, S. (2010). ABC of diabetes. Sixth Edition. Chicester. West Sussex: Wiley-Blackwel. A. John Wiley \& Sons, Ltd.

Ilyas, E.I. (2009). Buku Ajar Penyakit Dalam Jilid III Edisi 4. Jakarta: Departemen Ilmu Penyakit Dalam FKUI.

Ilyas, E.I. (2009). Olah raga Diabetes. Dalam: Soegondo, S., Soewondo, P., Subekti, I., Penatalaksanaan Diabetes Mellitus Terpadu. Jakarta: Fakultas Kedokteran Universitas Indonesia.

Lynne, B. (2012). Bugar dengan Senam Aerobik, Terjemahan anna Agustina. Jakarta: Raja Grafindo Persada.

Muhajir. (2006). Pendidikan jasmani dan Kesehatan. Jakarta: Yudhistira.

Notoatmojo, S. (2010). Metodologi Penelitian Kesehatan. Jakarta: Rineka Cipta.

Nursalam. (2013). Metodologi Penelitian Ilmu Keperawatan. Jakarta: Salemba Medika.

PERKENI. (2015). Konsensus Pengolahan dan Pencegahan Diabetes Melitus Tipe 2 di Indonesia. Jakarta: PB PERKENI. 
Purwanto. (2011). Dampak Senam Aerobik terhadap Daya Tahan Tubuh dan Penyakit. Jurnal Media Ilmu Keolahragaan Indonesia.Vol 1. Edisi 1. Juli 2011.

Saputra, L. (2014). Kapita Selekta. Kedokteran Klinik. Jakarta: Binarupa Aksara.

Sastroasmoro, S. (2011). Dasar-dasar Metodologi Penelitian Klnis. Jakarta: Sagung Seto.

Smelzer, S.C. (2008). Buku Ajar Keperawatan Medikal Bedah Brunner \& Suddrat. Jakarta: EGC.

Soegondo, S., Soewondo,P., \& Subekti, I. (2011). Penatalaksanaan Diabetes Melitus Terpadu. Jakarta: Fakultas Kedokteran Universitas Indonesia.
Sugiono. (2009). Metode Penelitian Kuantitatif dan Kualitatif. Bandung: Alfabeta.

Utomo, O.M., Azam, M., \& Anggraini, D.N. (2012). Pengaruh Senam Terhadap Kadar Gula Darah Penderita Diabetes. Unnes Journal of Public Health:1(1):36-40.

Waspadji, S., Soebekti, I., Yunir E. M., \& Sukardji, K. (2012). Petunjuk Praktis bagi Penyandang Diabetes Tipe 2. Jakarta: Fakultas Kedokteran Universitas Indonesia.

World Health Organization. Global Status Report or Non Communicable Diasease 2011. Aviable from www.who.org. Diakses pada 28 April 2018.

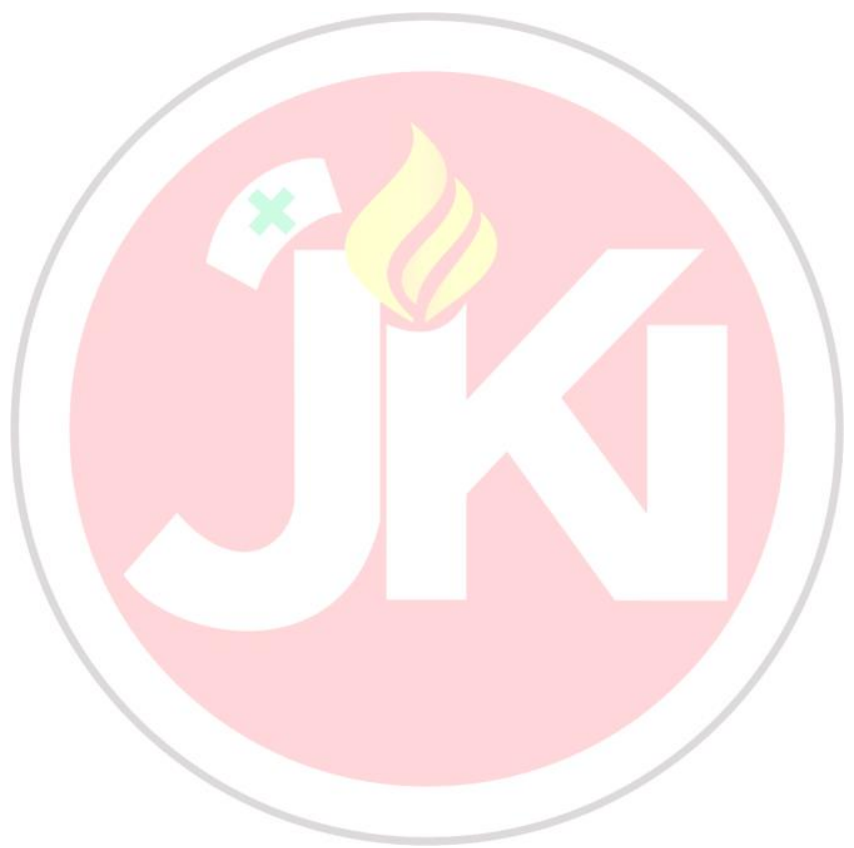

